female (10 persons) with iron deficiency anemia; III - female (10 persons) with $\mathrm{B}_{12}$-folic acid-deficiency anemia. Determination of the concentration of hemoglobin in the blood test was carried out photometrically tsianmetgemoglobinovim. Adaptable and reserve the possibility of cardiovascular system characterized by the best performance in people with vitamin $\mathrm{B}_{12}$-folic acid deficiency anemia and normal hemoglobin compared to women with iron deficiency anemia. Female in the control group and $\mathrm{B}_{12}$-folic acid deficiency anemia are characterized by a good level of functional state of the respiratory system, whereas subjects with IDA-average.

Key words: iron deficiency anemia, $\mathrm{B}_{12}$-folic acid-deficiency anemia, hemoglobin.

Стаття надійшла до редколегії 29.09.2016 р.

УДК 612.821:612 82/.83

\author{
Сергій Тукаєв, \\ Світлана Федорчук, \\ Людмила Чікіна, \\ Таїсія Герасько, \\ Ігор Зима, \\ Олександр Зайченко, \\ Юрій Гаврилець, \\ Володимир Різун, \\ Володимир Богданов, \\ Юрій Горго
}

\title{
Статичні електричні потенціали в біологічно активних зонах шкіри обличчя за умов формування емоційного вигорання в студентів
}

Статичні електричні потенціали (СТЕП) у біологічно активних зонах шкіри (БАЗ) відображають рівень фонової активації мозкових структур і рівень психічного стресу. Мета дослідження - виявити зв'язки СТЕП у симетричних біологічно активних зонах шкіри обличчя з рівнем емоційного вигорання в студентів. Виявлена зворотна кореляція між формуванням емоційного вигорання й рівнем електричного потенціалу шкіри в правих білявушних БАЗ $\left(\mathrm{r}_{s}=-.43, \mathrm{p}<.05\right)$ відносно долоні як референтної ділянки. Знайдено кореляції між розвитком стадії опору вигоранню та фоновими СТЕП у правих і лівих лобних БАЗ (відповідно, $\mathrm{r}_{s}=-.44$ i $\mathrm{r}_{s}$ $=-.47, \mathrm{p}<.05)$ і СТЕП у лівій лобній БАЗ після впливу негативних кадрів телевізійних новин $\left(\mathrm{r}_{s}=-.50, \mathrm{p}<.01\right)$. Це вказує на те, що формування емоційного вигорання знижує передпускову (до початку експерименту) емоційну напругу й відповідь, тобто силу реакції, на «зовнішні» негативні емоційні стимули. Отримані дані свідчать про те, що електродермальні потенціали можуть служити об'єктивними критеріями формування емоційного вигорання.

Ключові слова: статичні електричні потенціали (СТЕП), біологічно активні зони шкіри людини (БАЗ), рівень емоційного вигорання

Постановка наукової проблеми та її значення. Висока реактивність нервової системи часто є причиною неадекватної реакції організму на різні за силою подразники й лежить в основі тривожності особистості, яка в сукупності з високою емоційністю знижує надійність та ефективність розумової діяльності людини $[1 ; 2 ; 3]$, соціальну мотивацію й соціальні взаємодії особливо в ситуаціях неконтрольованого стресу [4; 5; 6]. Як відомо, одна 3 форм стресу - емоційне вигорання. Найбільш уразливими до вигорання особистості, які реагують на стрес агресивно [7; 8]. Проте на початку формування емоційного вигорання агресивність дає змогу зменшити негативний вплив емоційного стресу [7]. Ризик розвитку вигорання також збільшують такі особистісні риси: нейротизм, тривожність, низька самосвідомість, емоційна нестійкість [7; 9]. За тривалого розвитку емо-

(C) Тукаєв С., Федорчук С., Чікіна Л., Герасько Т., Зима І., Зайченко О., Гаврилейь Ю., Різун В., Богданов В., Горго Ю., 2016 
ційного вигорання виникають не лише психологічні проблеми, але також і супутні їм соматичні захворювання $[7 ; 10 ; 11 ; 12 ; 13]$.

Водночас відомо, що значення статичних електричних потенціалів (СТЕП - «skin potential level») у біологічно активних зонах (БАЗ) шкіри обличчя певною мірою відображають рівень фонової активації мозкових структур, тобто рівень нервово-психічного напруження людини $[10 ; 14 ; 15 ; 16 ; 17]$. Електродермальні потенціали (ЕП) у симетричних біологічно активних зонах шкіри обличчя можуть слугувати показниками ефективності розумової діяльності людини незалежно від рівня емоційного напруження [1; 2]. Крім того, деякі дослідники зазначають, що для гіперактивних, агресивних осіб характерна електродермальна гіпореактивність [18]. Наразі відомо лише одну роботу [19], у якій вимір рівня ЕП застосовували для оцінки ефективності 5-тижневого курсу музичної терапії в знятті симптомів емоційного вигорання. Різкі зміни електричних потенціалів спокою (переважно іпсілатеральні) в активних точках шкіри голови супроводжують патологічні ураження окремих відділів кори головного мозку, його оболонок і мозочка за умов неушкоджених нервових зв'язків між головним мозком, оболонками й шкірою [20; 21]. Про зв'язок СТЕП із психічними та метаболічними розладами зазначала також В. А. Ілюхіна зі співавторами [22]. За даними багатьох дослідників причина розподілу електричних потенціалів шкіри голови залежно від локалізації патологічного процесу або фізіологічної активності внутрішніх органів і структур центральної нервової системи - у різних джерелах іннервації [20; 21]. Зворотні зв'язки БАЗ шкіри людини зі структурами ЦНС (центральної нервової системи) і внутрішніми органами зазвичай розглядають як рефлекторні. Специфіка цих явищ полягає в тому, що вони здійснюються симпатичною нервовою системою й проявляються у вигляді коливань електричних потенціалів і температури [20].

Отже, можна зробити цілком логічне припущення, що формування вигорання може позначатися на зміні значень статичних електричних потенціалів обличчя.

Об'єкт і методи досліджень. У проведеному дослідженні брав участь 31 студент I-III курсів Київського національного університету імені Тараса Шевченка (Навчально-наукового центру «Інститут біології» і факультету психології) віком $17-23$ роки обох статей $(M=19,07, S D=1,91)$. Для оцінки наявного психічного стану студентів (а саме вихідного рівня емоційного вигорання) застосовано тест діагностики рівня емоційного вигорання В. В. Бойка [11], адаптований для професійної групи «студенти» [7; 9] з урахуванням особливостей вибірки та ситуації взаємодії в процесі навчання. Методика дає змогу діагностувати механізм психологічного захисту у формі повного або часткового виключення емоцій у відповідь на психотравмувальні впливи та, як наслідок, - здатність людини сприймати й обробляти будь-який вид інформації. Синдром емоційного вигорання класифікують за стадіями (тривожне напруження, опір (резистенція) і виснаження), для яких характерні ті чи інші симптоми, що враховують зміни параметрів психологічної та емоційної активності. В. Бойко розглядає вигорання як динамічний процес, що виникає поетапно відповідно до механізму розвитку стресу й проходить три фази. Нервове напруження за умов посилення психотравмувальних факторів запускає формування емоційного вигорання (фаза «Тривожне напруження»). Фаза «Резистенції» характеризується опором щодо наростаючого стресу за рахунок виключення емоцій (розширення сфери економії емоцій, емоційно-моральна дезорієнтація й т. ін.). Падіння загального енергетичного тонусу та ослаблення нервової системи виражено у фазі «Виснаження». Значення кожної з фаз вимірюється за шкалою від 0 до 120 пунктів: від 0 до 36 балів - фаза не сформована, 37-60 балів - фаза перебуває на стадії формування, 61-120 балів - фаза сформована [11].

Значення СТЕП у БАЗ шкіри обличчя в досліджуваних заміряли на початку досліджень і безпосередньо перед проходженням тестів із використанням емоційно негативних стимулів (вихідний рівень - фон 1 і фон 2), наприкінці експерименту (післядія - ПД). Завдання учасників - стежити за появою на екрані двох добірок по 75 зображень кожна з негативних і нейтральних ТВ (телевізійних) новинних сюжетів (загальний час серії - 6-7 хв). Абсолютні значення статичних електричних потенціалів шкіри (рисунок) у симетричних (правих та лівих) БАЗ шкіри обличчя: лобних (ЛП, ЛЛ), надбрівних (НП, НЛ), біляносових (БНП, БНЛ), скроневих (СП, СЛ), білявушних (БВП, БВЛ) і завушних (ЗВП, ЗВЛ) реєстрували неполяризуючими хлорсрібними електродами за допомогою потенціометра постійної напруги «БІО-1» із підвищеним вхідним опором, що перешкоджає виникнен- 
ню струмів витоку через шкіру, та із вхідним фільтром частот, котрий відсікає всі частоти, вищі за 0,1 Гц, запобігаючи небажаному впливу електричної активності серця й інших внутрішніх органів на досліджувані потенціали шкіри [20; 23; 24]. Довготривало неполяризованими електродами $є$ металеві стрижні, покриті шаром $\mathrm{AgCl}$, що поміщались у фізіологічний розчин, яким наповнювали корпус електрода. Корпус електрода виготовлено з нейтрального матеріалу. Реєстрація СТЕП відбувалася таким чином: обстежуваний перебував у положенні сидячи. Біологічно активні ділянки шкіри знежирювалися за допомогою спирту. Індиферентний електрод зі змоченим у фізіологічному розчині гнітом довжиною 5 см затискався в долоні обстежуваного (референтна зона), яка являлась електронегативною зоною відносно зон на шкірі голови. Згідно з А. К. Подшибякіним [20], слизові оболонки, долоні та підошви $є$ електронегативними відносно інших зон шкіри. До того ж електричний потенціал у цих зонах відзначається сталістю, тому поверхні долонь, підошов і слизові оболонки використовують як індиферентні зони. Активним електродом із коротким, змоченим у фізіологічному розчині гнітом з однаковою силою натискання торкалися до шкіри в обраній зоні й проводили вимір електричного потенціалу між долонею та вибраною БАЗ.

Дані про значення шести обраних БАЗ досить різноманітні. Класичні дослідження А. К. Подшибякіна стосовно розподілу активних точок і зон на шкірі людини свідчать про зв'язок обраних нами БАЗ зі структурами головного мозку [20; 21]. Так, дані, отримані на хворих і здорових обстежених, дають змогу простежити зміни в лобних і надбрівних БАЗ у відповідь на функціональну активність лобних відділів мозку [21]. Проте саме лобні БАЗ візуально збігаються з гепатобіліарними симетричними зонами краніопунктури (тобто зонами однієї з мікроакупунктурних систем, котрі розташовані в ділянці скальпа), що використовуються для рефлексотерапії хвороб печінки й жовчних шляхів [25]. Загалом, до вимірюваних БАЗ візуально можна віднести досить велику кількість біологічно активних точок (БАТ), що в акупунктурній діагностиці та рефлексотерапії використовуються для профілактики й лікування багатьох захворювань і больових синдромів різного генезу [25; 26; 27]. Усі ці відомості дають підставу об' єднати обрані БАЗ як специфічні фізіологічні маркери насамперед рівня активації головного мозку та, крім того, загального функціонального стану здорової людини.

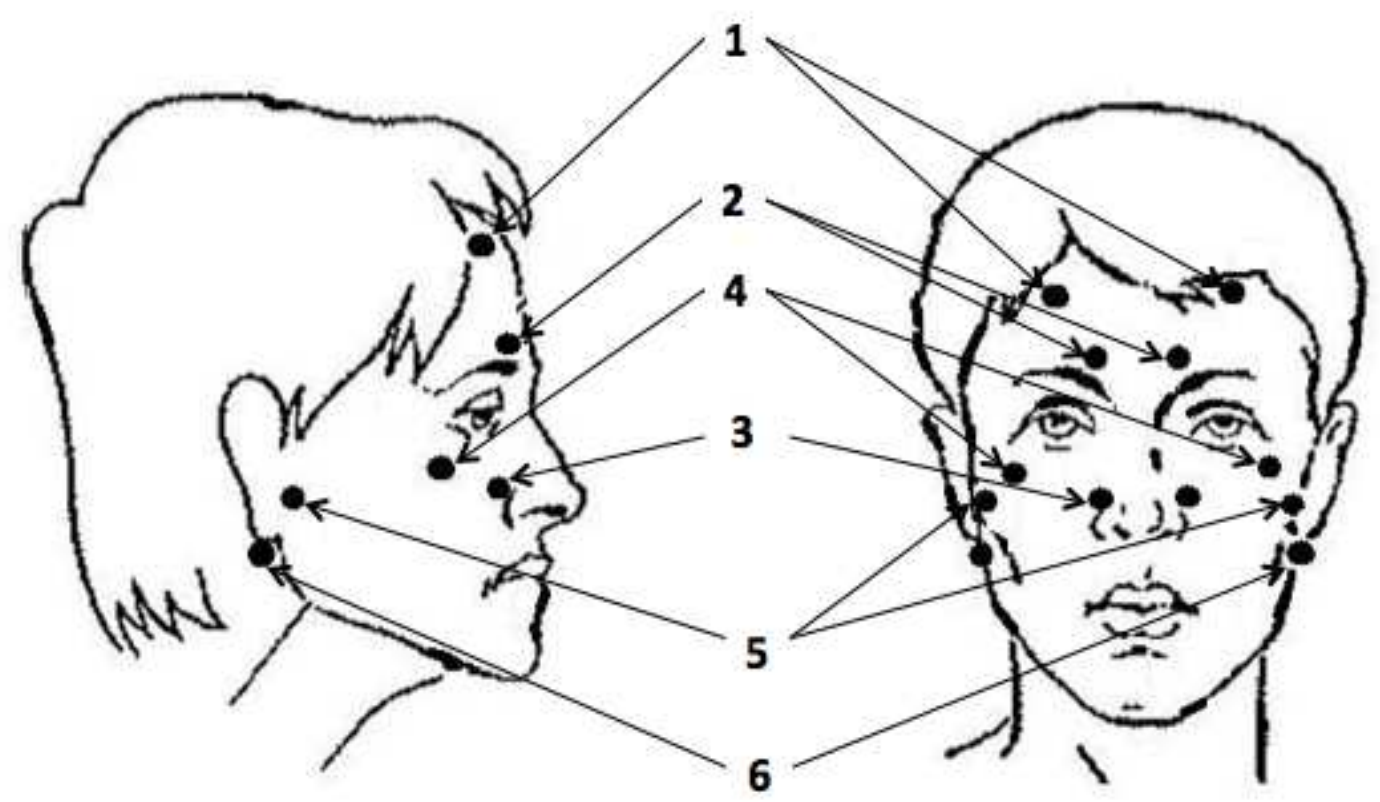

Рис. 1. Розташування досліджуваних БАЗ шкіри обличчя : 1 -лобні; 2 - надбрівні; 3 - біляносові; 4 - скроневі; 5 - білявушні; 6 - завушні

Статистичну обробку даних проводили з використанням методів математичної статистики за допомогою статистичного пакета Statistica 8. Для визначення нормальності розподілу даних застосовували критерій Колмагорова-Смірнова. Для дослідження кореляційних зв'язків використовували тест Спірмена. 
Виклад основного матеріалу й обгрунтування отриманих результатів дослідження. За запропонованим тестом В. В. Бойка [11] визначали окремо три фази розвитку синдрому емоційного вигорання: фазу напруження (для оцінки реакції на зовнішні й внутрішні фактори), фазу резистенції (для оцінки прийомів психологічного захисту) та фазу виснаження (для оцінки стану нервової системи студентів). Залежно від рівня сформованості кожної окремої фази (напруження, резистенції, виснаження) синдрому емоційного вигорання обстежених розподілено на три групи: 1 - фазу не сформовано, 2 - фаза на стадії формування, 3 - фазу сформовано.

На думку науковців, зміни електродермальних потенціалів із розвитком емоційного вигорання можуть бути пов'язані опосередковано, відповідно до типу вегетативного регулювання або індивідуально-типологічних особливостей чи особистісних характеристик. Наприклад, якщо групи студентів, розподілені за рівнем виснаження, будуть більш схожими (змішаними) як за типом вегетативного реагування, так і за особистісними характеристиками, то статистична обробка групових даних нівелює вплив емоційного вигорання на рівень ЕП. Зважаючи на отримані результати, студенти з різним рівнем сформованості фази резистенції більш вірогідно відрізнятимуться за типом вегетативного реагування або певними особистісними характеристиками. Проте ці припущення, безумовно, потребують подальших досліджень і підтверджень або спростувань.

Як відомо, у нормі симпатичний та парасимпатичний відділи вегетативної нервової системи (ВНС) існують у тісній взаємодії, проте міра прояву тих й інших реакцій може бути різною. Різноспрямований характер зрушень вегетативних показників залежить від індивідуального превалювання симпатичного або парасимпатичного реагування [28; 29]. У здорових обстежених, за даними багатьох дослідників, простежено чітке співвідношення емоційних і вегетативних процесів: відсутність емоційних порушень супроводжується вегетативною ейтонією (нормотонією). Проте прояв «тривожності» в структурі особистості (при порівнянні $з$ упевненістю, демонстративністю й егоцентризмом) супроводжується більш вираженими коливаннями у вегетативній нервовій системі, у тому числі - у відповідь на негативний емоційний стимул [30]. У реєстрованій середній амплітуді ШГР (шкірно-гальванічної реакції) відбивається зв'язок домінування та готовності / неготовності піти на поступки при агресивному дискурсі [31]. Крім того, відомо, що особам із переважним збудженням симпатичної нервової системи притаманна активація діяльності, психічна спрямованісь на дію, витрачання сил й енерговитрати [32]. Для осіб із переважним збудженням парасимпатичної нервової системи властиве накопичення внутрішньоособистісних конфліктів і проблем, формування стану підвищеного енергодефіциту, необхідність відновлення, накопичення енергетичних запасів, збільшення потреби у відпочинку [32]. Симпатотонікам при емоційному стресі більш характерна стенічна, агресивна поведінка, тоді як ваготоніки більше схильні до депресії, філософського погляду на життя. Превалювання симпатичної регуляції забезпечує покращення адаптивних можливостей, оскільки сприяє генералізації нервових процесів, підвищує сенсорну чутливість і додає організму сил діяти адекватно до ситуації. Превалювання парасимпатичної регуляції погіршує адаптивні можливості [33; 34]. Можливо, особи з переважним збудженням парасимпатичної нервової системи будуть більш схильні до емоційного вигорання.

Кореляційний аналіз отриманих результатів підтвердив, що формування емоційного вигорання за інтегративним показником (таблиця) супроводжувалося зменшенням фонових СТЕП у білявушних правих БАЗ шкіри обличчя $\left(\mathrm{r}_{s}=-.43, \mathrm{p}<.05\right)$. Крім того, виявлено значущі обернені кореляційні зв'язки рівня резистенції з фоновими СТЕП у правих і лівих лобних БАЗ (відповідно, $\mathrm{r}_{s}=-$


$\left.\mathrm{r}_{s}=-.50, \mathrm{p}<.01\right)$. Тобто при вищому вихідному рівні емоційного вигорання за наведеними вище біофізичними параметрами БАЗ відбувалося зменшення фонового (вихідного) емоційного напруження, а також зменшення сили реакції на «зовнішній» негативний емоційний стимул. Отримані результати в цілому узгоджуються з літературними даними щодо формування «емоційної прямоти, притуплення» (emotional bluntness), зниження або відсутності реакції на негативно забарвлені стимули впродовж розвитку емоційного вигорання [35]. Саме використання спеціальних прийомів психологічного захисту в обстежених найбільше викликало зниження СТЕП. Ні напруження (як реакція на зовнішні або внутрішні фактори), ні формування виснаження нервової системи так не відобразилися на динаміці СТЕП, як формування фази резистенції. 
Кореляційні зв'язки (за Спірменом) статичних електричних потенціалів у біологічно активних зонах шкіри 3 рівнем емоційного вигорання студентів $(n=31), r_{s}$

\begin{tabular}{|l|c|}
\hline \multicolumn{1}{|c|}{ Показник } & \multicolumn{1}{|c|}{ Кореляційні зв'язки, $\boldsymbol{r}_{S}$} \\
\hline Рівень резистенції - ЛП-ФОН1 & $-.44^{*}$ \\
\hline Рівень резистенції - ЛЛ-ФОН1 & $-.47^{*}$ \\
\hline Рівень резистенції - ЛЛ-Т3 & $-.50^{* *}$ \\
\hline Загальний рівень емоційного вигорання - БВП-ФОН1 & $-.43^{*}$ \\
\hline
\end{tabular}

Примітки.

$* p<.05, * * p<.01$;

ЛП, ЛЛ; БВП - абсолютні значення статичних електричних потенщуіалів (СТЕП, мВ) у БАЗ шкіри обличчя: відповідно симетричних (правих та лівих) лобних і правих білявушних;

ФОН1 - фонові СТЕП, ТЗ - СТЕП після тестування.

Проте залишається відкритим питання про те, чи нормалізує включення прийомів психологічного захисту функціональний стан, чи збільшує «фізіологічну ціну» емоційного вигорання. Можливо, ідеться про більш емоційну стійкість студентів як на стадії формування, так і при сформованій фазі резистенції.

Отже, аналіз отриманих результатів розподілу СТЕП у БАЗ шкіри обличчя дає підставу для висновку: електродермальні потенціали певною мірою можуть слугувати об' єктивними критеріями рівня формування емоційного вигорання (передусім фази резистенції). Тому очевидно, що показники СТЕП у БАЗ шкіри обличчя можуть бути використані в діагностиці загального рівня емоційного вигорання.

Висновки та перспективи подальшого дослідження. Електродермальні потенціали певною мірою можуть слугувати об'єктивними критеріями рівня формування емоційного вигорання. Зв'язки рівня електродермальних потенціалів у біологічно активних зонах шкіри обличчя 3 показниками фази резистенції й загального рівня емоційного вигорання вказують на зниження передпускової (до початку експерименту) емоційної напруги та відповіді, тобто сили реакції, на «зовнішні» негативні емоційні стимули при формуванні емоційного вигорання. Показники СТЕП у БАЗ шкіри обличчя потребують подальшого більш детального дослідження для використання в діагностиці загального рівня емоційного вигорання.

\section{Джерела та література}

1. Горго Ю. П. Психофізіологія (прикладні аспекти) / Ю. П. Горго. - К. : Вид. МАУП, 1999. - 123 с.

2. Федорчук С. В. Психофізіологічні показники розумової діяльності людини / С. В. Федорчук, Л. В. Чікіна, В. Б. Богданов, Ю. П. Горго // Вісник Київського університету. - Серія «Біологія». - 2003. - Вип 40. C. $83-85$.

3. Edwards M. S. Cognitive trait anxiety, stress and effort interact to predict inhibitory control / M. S. Edwards, E. J. Edwards, M. Lyvers // Cognition and Emotion, 2016. - 1-16. [Elektronik resourse]. - Mode of access : http://dx.doi.org/10.1080/02699931.2016.1152232

4. Arnsten A. F. Stress weakens prefrontal networks: molecular insults to higher cognition / A. F. Arnsten // Nature neuroscience. - 18(10). - - 2015. - P. 1376-1385. doi: 10.1038/nn.4087

5. Sandi C. Stress and the social brain: behavioural effects and neurobiological mechanisms / C. Sandi, J. Haller // Nature Reviews Neuroscience. - 16(5). - 2015. - P. 290-304. doi:10.1038/nrn3918

6. Chadwick A. E. Communication and Stress: Effects of Hope Evocation and Rumination Messages on Heart Rate, Anxiety, and Emotions After a Stressor / A. E. Chadwick, P. M. Zoccola, W. S. Figueroa, E. M. Rabideau // Health communication. - 2016. - 1-13. [Elektronik resourse]. - Mode of access : http://dx.doi.org/ $10.1080 / 10410236.2015 .1079759$

7. Тукаев С. В. Психологические и нейрофизиологические аспекты развития синдрома эмоционального выгорания / С. В. Тукаев, Т. В. Вашека, И. Г. Зима // Актуальные аспекты внутренней медицины : кол. науч. моногр. ; [под ред. В. П. Волкова]. - Новосибирск : Изд-во «СибАК», 2013 - 112 с. - С. 86-107. DOI: $10.13140 /$ RG.2.1.2429.3845

8. Tukaiev S. V. The relationships between burnout and aggression in psychology students / S. V. Tukaiev, O. M. Radchuk, T. V. Vasheka // Česká a slovenská psychiatrie. - 108 (Suppl. 1). - 2012. - P. 262. [Elektronik resourse]. - Mode of access : http://www.guarant.eu/wpaic2012/wpaic-2012-abstracts.pdf 
9. Вашека Т. В. Детермінанти емоційного вигоряння студентів-психологів в процесі навчання / Т. В. Вашека, С. В. Тукаєв // Проблеми загальної та педагогічної психології : зб. наук. пр. Ін-ту психології ім. Г. С. Костюка Нац. АПН України. - ХІІІ(6). - 2011. - 47-55.

10. Горлов Д. С. Електродермальний потенціал при афективній відеостимуляції у осіб із різними рівнями емпатії / Д. С. Горлов, М.Ю.Макарчук, В. Б. Богданов [та ін.] // Біологічні студії / Studia Biologica. 2010. - Т. 4, № 1. - С. 63-70.

11. Водопьянова Н. Е. Психодиагностика стресса / Н. Е. Водопьянова. - СПб. : Издат. дом «Питер», 2013. $336 \mathrm{c}$.

12. Балахонов А. В. Эмоциональное выгорание у медицинских работников как предпосылка астенизации и психосоматической патологии / А. В. Балахонов, В. Г. Белов, Е. Д. Пятибрат, А. О. Пятибрат // Вестник Санкт-Петербургского университета. - Серия 11 : Медицина. - (3). - 2009. - С. 57-71 [Электронний ресурс]. - Режим доступа : https://med.spbu.ru/archiv/vest/9_3/3_07.pdf

13. Малкина-Пых И. Психосоматика / И. Малкина-Пых // Litres, -2013 . - 3020 с.

14. Богданов В. Б. Застосування асиметрії статичного електричного потенціалу і часу простої сенсомоторної реакції для визначення типу реагування людини за різного вихідного рівня емоційної напруги / В. Б. Богданов, Д. С. Горлов, А. І. Сна, Ю. П. Горго // Інформотерапія: теоретичні аспекти та практичне застосування : матеріали ХІІ Міжнар. конф. (6-8 жовт. 2006 р.). - К., 2006. - Інформаційна та негентропійна терапія. - №1. - 2006. - С. 9-10.

15. Котельников С. А. Вызванные кожные вегетативные потенциалы (современные представления о механизмах) / С. А. Котельников, А. Д. Ноздрачёв, М. М. Одинак, Е. Б. Шустов // Физиология человека. - 26(5). - 2000. - C. 79-91.

16. Vetrugno R. Sympathetic skin response: basic mechanisms and clinical applications / R. Vetrugno, R. Liguori, P. Cortelli, P. Montagna // Clinical Autonomic Research. - 13(4), - 2003. - C. 256-270. doi: 10.1007/s10286-003-0107-5

17. Макарчук М. Ю. Електрофізіологічні й психофізіологічні реакції обстежуваних за умов підвищеної відповідальності за результати діяльності / М. Ю. Макарчук, Л. В. Чікіна // Вісник КНУ ім. Т. Шевченка. Проблеми регуляції фізіологічних функцій. - 2005. - № 10. - С. 13-15.

18. Fowles D. C. Electrodermal hyporeactivity and antisocial behavior / D. C. Fowles, A. M. Furuseth // In Disruptive behavior disorders in childhood. - 1994. - P. 181-205. - Springer US.

19. Brandes V. Music programs designed to remedy burnout symptoms show significant effects after five weeks / V. Brandes, D. D. Terris, C. Fischer [et al.] // Annals of the New York Academy of Sciences. - 1169(1)/ 2009. - P. 422-425. DOI: 10.1111/j.1749-6632.2009.04790.x

20. Подшибякин А. К. Значение активных точек кожи для эксперимента и клиники : автореф. дис. ... канд. мед. наук. / А. К. Подшибякин. - Киев, 1960. - 32 с.

21. Подшибякин А.К. Распределение электрических потенциалов покоя кожи головы при экспериментальных воздействиях и ограниченных поражениях головного мезга / А. К. Подшибякин // Журнал невропатологии и психиатрии - 1962. - Т. 62. - Вып. 10. - С. 1464-1469.

22. Ілюхина В. А. Психофизиология функциональных состояний и познавательной деятельности здорового и больного человека / В. А. Ілюхина. - СПб. : Изд-во Н-Л, 2010. - 368 с.

23. Богданов В. Б. Дослідження зв'язків електрофізіологічних характеристик шкіри та індивідуально-типологічних особливостей людини : автореф. дис. ... канд. біол. наук / В. Б. Богданов. - К., 2005. - 20 с. [Електронний ресурс]. - Режим достуру : http://www.irbis-nbuv.gov.ua/cgi-bin/irbis_nbuv/cgiirbis_64.exe? C21COM=2\&I21DBN=ARD\&P21DBN=ARD\&Z21ID=\&Image_file_name=DOC/2005/05bvbtol.zip\&IMA GE_FILE_DOWNLOAD=1

24. Горлов Д. С. Методичні особливості вимірів розподілу статичних електричних потенціалів на поверхні шкіри людини / Д. С. Горлов, В. Б. Богданов, Ю. П. Горго // Інформотерапія: теоретичні аспекти та практичне застосування : матеріали Х Ювілейної міжнар. конф. (28-31 жовт., 2004 р.). - К., 2004. Інформаційна та негентропійна терапія. - №1. - С. 88-91.

25. Мачерет Е. Л. Атлас акупунктурных зон / Е. Л. Мачерет, В. П. Лысенюк, И. З. Самосюк. - Киев, 1986. C. 117.

26. Петренко В. М. Квазисегментарное устройство тела человека / В. М. Петренко // Международный журнал прикладных и фундаментальных исследований. Медицинские науки. - 2014. - №. 8-1. С. $59-62$.

27. Самосюк И. 3. Акупунктура. Энциклопедия / И. З. Самосюк, В. П. Лысенюк. - Киев ; Москва, 1994.

28. Kosonogov V. Facial temperature depends on the arousing content of emotional pictures / V. Kosonogov, L. De Zorzi [et al.] // Autonomic Neuroscience: Basic and Clinical, 192, - 2015. - 36. doi:10.1016/ j.autneu.2015.07.366 
29. Горлов Д. С. Електричні потенціали шкіри в осіб з різними показниками тесту «Синдром хронічної втоми» / Д. С. Горлов, М. Ю. Макарчук, В. Б. Богданов, Т. В. Куценко, В. А. Харченко // Вісник Луганського національного університету імені Тараса Шевченка. - 2010. - № 21 (208). - С. 35-42.

30. Вейн А. М. Вегетососудистая дистония / А. М. Вейн, А. Д. Соловьева, О. А. Колосова. - М. : Медицина, 1981. - 320с.

31. Brandstätter H. Towards differential social psychology: Individual differences in responding to an aggressive discussant / H. Brandstätter // In G. R. Semin \& B. Krähe (Eds.). - Issues in contemporary German Social Psycholgy. - History, Theories and Application. - 1987. - P. 55-73. - London : Sage, 1987 [Elektronik resourse]. - Mode of access : (http://nbn-resolving.de/urn:nbn:de:bsz:291-psydok-40394)

32. Воронова В. Психологическое обеспечение подготовки спортсменов в футболе / В. Воронова // Наука в олимпийском спорте. - Вип. 4. - 2013. - С. 32-39.

33. Китаев-Смык Л. А. Психология стресса. Психологическая антропология стресса / Л. А. Китаев-Смык. М. : Академический проект, 2009. - 943 с.

34. Китаев-Смык Л. А. Выгорание персонала. Выгорание личности. Выгорание души / Л. А. Китаев-Смык // Психопедагогика в правоохранительных органах. - 2(33). - 2008. - С. 41-50.

35. Tukaiev S. Does the response to negative TV news depend on the level of emotional burnout? / S. Tukaiev, I. Zyma [et al.] // Program № 268.21/TT34. - 2014. Neuroscience Meeting Planner.Washington, DC : Society for Neuroscience, 2014. Online // Neuroscience 2014. - SfN's 44st annual meeting. - November 15-19. Washington, DC, USA, 2014. - P. 1585-1586.

36. http://www.sfn.org/ /media/SfN/Documents/Annual\%20Meeting/FinalProgram/NS2014/FullAbstractPDFs_ 2014/SFN2014_Abstracts_PDF_Sun_PM.ashx

Тукаев Сергей, Федорчук Светлана, Чикина Людмила, Герасько Таисия, Зима Игорь, Зайченко Александр, Гаврилец Юрий, Ризун Владимир, Богданов Владимир, Горго Юрий. Статические электрические потенциалы в биологически активных зонах кожи лица в условиях формирования эмоционального выгорания у студентов. Статические электрические потенциалы (СТЭП) в биологически активных зонах кожи лица (БАЗ) отражают уровень фоновой активации мозговых структур и уровень психического стресса. Как известно, одной из форм стресса является эмоциональное выгорание. Синдром эмоционального выгорания классифицируется в соответствии со стадиями (тревожное напряжение, сопротивление (резистенция) и истощение), для которых характерны те или иные симптомы, учитывающие изменения параметров психологической и эмоциональной активности. В. Бойко рассматривает выгорание как динамический процесс, который возникает поэтапно в соответствии с механизмом развития стресса и проходит три фазы. Нервное напряжение при усилении психотравмирующих факторов запускает формирование эмоционального выгорания (фаза «Тревожное напряжение»). Фаза «Резистенции» характеризуется сопротивлением нарастающему стресса за счет выключения эмоций (расширения сферы экономии эмоций, эмоционально-моральной дезориентации и т. д.). Падение общего энергетического тонуса и ослабление нервной системы выражено в фазе «Истощение».

Цель исследования - обнаружить изменения СТЭП в симметричных биологически активных зонах кожи лица в зависимости от уровня эмоционального выгорания.

В исследовании принял участие 31 студент I-III курсов Киевского национального университета имени Тараса Шевченко (Учебно-научного центра «Институт биологии» и факультета психологии) в возрасте 1723 года $(M=19.07, S D=1.91)$. Для оценки психологического состояния студентов (а именно исходного уровня эмоционального выгорания) использован тест диагностики уровня эмоционального выгорания В. В. Бойко, адаптирован для профессиональной группы «студенты» (С. В. Тукаев, Т. В. Вашека) с учетом особенностей выборки и ситуаций взаимодействия в процессе обучения. Методика позволяет диагностировать механизм психологической защиты в форме полного или частичного выключения эмоций в ответ на психотравмирующие влияния и, как следствие, - способность человека воспринимать и обрабатывать какой-либо вид информации.

Абсолютные значения статических электрических потенциалов кожи в симметричных (правых и левых) БАЗ кожи лица (лобных, надбровных, околоносовых, височных, околоушных и заушных) регистрировали неполяризующимися хлорсеребряными электродами с помощью потенциометра постоянного напряжения с повышенным входным сопротивлением. Значения СТЭП в БАЗ кожи лица в обследованных замеряли в начале исследования, непосредственно перед прохождением тестов с использованием эмоционально негативных стимулов и в конце исследования.

Выявлена обратная корреляция между формированием эмоционального выгорания и уровнем электрического потенциала кожи в правых околоушных БАЗ $\left(\mathrm{r}_{s}=-.43, \mathrm{p}<.05\right)$ относительно ладони в качестве референтной зоны. Найдены корреляции между развитием стадии сопротивления выгоранию и фоновыми СТЭП в правых и левых лобных БАЗ (соответственно, $\left.\mathrm{r}_{s}=-.44 \mathrm{i} \mathrm{r}_{s}=-.47, \mathrm{p}<.05\right)$ и СТЭП в левой лобной БАЗ после воздействия негативных кадров телевизионных новостей $\left(\mathrm{r}_{s}=-.50, \mathrm{p}<.01\right)$. Это указывает на то, что формирование эмоционального выгорания снижает фоновое (перед экспериментом) исходное эмоциональное 
напряжение и ответ, т. е. силу реакции на «внешние» негативные эмоциональные стимулы. Полученные данные свидетельствуют о том, что электродермальные потенциалы могут служить объективными критериями формирования эмоционального выгорания.

Ключевые слова: статические электрические потенциалы (СТЭП), биологически активные зоны кожи человека (БАЗ), уровень эмоционального выгорания.

Tukaiev Sergii, Fedorchuk Svitlana, Chikina Liudmyla, Gerasko Taisia, Zy ma Igor, Zaichenko Aleksandr, Havrylets Yurii, Rizun Volodymyr, Bogdanov Volodymyr, Gorgo Yurii. The Skin Potential Level of Facial Biologically Active Zones as Indicators of the Level of Emotional Burnout in Students.

Introduction. Emotional burnout syndrome sees as a reaction to stress in interpersonal communication in the form of full or partial shutdown of emotions. V. Boyko dynamic model of burnout that was used as basis of this study classified in 3 stages in accordance with the mechanism of stress. There exist 3 phases: Anxiety Tension, Resistance, and Exhaustion. Strengthening of stressful factors in everyday life triggers the formation of emotional burnout (Anxiety Tension stage). The respondents with «Resistance» stage begin to economize emotion and characterize by emotional and moral disorientation. The central nervous activity reduction and the fall in energy tone are evident in the «Exhaustion» stage. Inadequate reactions to the different stimulus are associated with the hyperreactivity of the nervous system. The skin potential level (SPL) of facial biologically active zones (BAZs) reflects the level of background activation of brain structures and the level of mental stress. That is why skin potential level reflects the formation of emotional burnout.

Purpose. The aim of the study was to detect the changes of SPL in symmetric biologically active zones of face skin (frontal, superciliary, paranasal, temporal, periotic and postaural) depending on the level of emotional burnout.

Methods. 31 healthy volunteers (women and men) - first-third year students $\left(\mathrm{M}_{\mathrm{age}}=19.07, \mathrm{SD}=1.91\right.$ years, from 17 to 23 years) were recruited from the Taras Shevchenko National University of Kyiv, Educational and Scientific Centre «Institute of Biology and Medicine» and Faculty of Psychology, and participated for course credit during preexam period. Skin potential level was recorded via nonpolarizable silver electrodes from the symmetric biologically active zones of face skin (frontal, superciliary, paranasal, temporal, periotic and postaural) with the palm as a reference area. To determine the stages of burnout we used the Boyko «Syndrome of emotional burnout» test adapted for students by Tukaiev and Vasheka. The value of each of Burnout stages was measured on a scale from 0 to 120 points: 0 to 36 points - the stage was not formed, 37 to 60 points - the stage was under development, 61 to 120 points - the stage was formed. The Speerman rank test was carried out for the correlation analysis.

Results. Inverse correlation was found between the formation of emotional burnout and the skin potential level in right periotic BAZ (parotid BAZ) $(\mathrm{r}=-.43, \mathrm{p}<.05)$. We found correlation between the development of the Resistance stage of burnout and background SPL in the right and left frontal BAZ (respectively $r=-.44$ and $r=-.47, p<.05$ ) and SPL in the left frontal BAZ after the exposure of negative frames of documentaries $(r=-.50, p<.01)$.

Conclusion. Our data indicates that the formation of burnout reduced the prestarting initial emotional tension and response strength to «external» negative emotional stimuli. It indicates that electrodermal potentials can serve as objective criteria of formation of emotional burnout.

Key words: skin potential level (SPL), biologically active zones (BAZs), emotional burnout.

Стаття надійшла до редколегії 24.09.2016 р.

УДК $612.82 / .83 ; 612.821$

\author{
Артем Охрей, \\ Тетяна Куценко, \\ Микола Макарчук
}

\section{Моторна асиметрія в музикантів і немузикантів під час оцінки оперативної пам'яті й уваги}

Оцінено швидкість та ефективність виконання тесту Струпа й тесту з оцінки оперативної пам'яті в музикантів і немузикантів. Установлено, що музиканти та немузиканти однаково ефективно виконують прямий і зворотний тести Струпа, а також не різняться за показниками розвитку оперативної пам'яті, проте під час виконання обох тестових завдань у музикантів моторна асиметрія реакцій правої й лівої рук $є$ меншою.

Ключові слова: моторна асиметрія, оперативна пам'ять, прямий і зворотний тести Струпа, музиканти, немузиканти.

(C) Охрей А., Куцеенко Т. Макарчук М., 2016 